\title{
Neonatal resuscitation program provider courses in Turkey
}

\section{Türkiye yenidoğan canlandırma programı (NRP) uygulayıcı kursları}

\author{
Başak TEZEL ${ }^{1}$, Mustafa ILHAN ${ }^{3}$, İlker GÜNAY ${ }^{2}$, Sema ÖZBAŞ $^{1}$

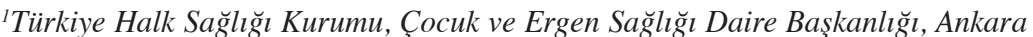 \\ ${ }^{2}$ Dr. Behçet Uz Çocuk Hastalıkları ve Cerrahisi Ĕ̈itim ve Araştırma Hastanesi, İzmir \\ ${ }^{3}$ Gazi School of Medicine, Department of Public Health, Ankara
}

\begin{abstract}
Objective: We aimed to reveal the factors effecting the success rates of participants and change in their levels of knowledge following Neonatal Resuscitation Program (NRP) courses in our country.

Methods: Type of our study is descriptive. Electronic and printed course report files were used for data collection. From course reports data about participants including their occupation, specialty, working place, gender, results of pre-test, post-test, final and practice exams were obtained.

Results: In the second half of 2007, 1411 health workers attended NRP provider courses. Difference between pre and post-test results was significant. A final exam was given to the participants at the end of the provider course which aimed to evaluate the course and participants and also as a legislative necessity for certification. Mean score of the participants was $94.8 \pm 4.7$ for written test and $95.5 \pm 4.5$ for practice exam. Also differences were found in the results of pre-test, post-test, written and practice exams with respect to occupation, working place and gender of the patients

Conclusion: NRP training achieved a significant increase in knowledge and skill levels of the health workers in our study group. In order to assess impact of NRP on levels of practice, knowledge and skills, the participants should be evaluated during a follow-up period after training.
\end{abstract}

Key words: Neonatal resuscitation, in-service training; asphyxia

\section{ÖZET}

Amaç: Ülkemizde yapılan Yenidoğan Canlandırma Programı (Neonatal Resuscitation Program- NRP) kurslarını izleyerek katılımcıların başarı düzeyini etkileyen etkenleri ve bilgi düzeyi değişikliklerini belirlemeyi hedefledik.

Yöntemler: Çalışmamız tanımlayıcı tipteydi. Veri toplamak için kâğıt üzerindeki ve elektronik ortamdaki kurs raporları kullanıldı. Kurs raporlarından toplanan katılımcı bilgileri; meslek, uzmanlık dalı, çalışılan yer, cinsiyet, ön test, son test, son sınav ve uygulama sınavı sonuçları idi.

Bulgular: NRP uygulayıcı kurslarına 2007 yılının ikinci yarısında toplam 1411 sağlık çalışanı katıldı. Ön test-son test arasında anlamlı bir fark vardı. Uygulayıcı kursunun sonunda kursu ve katılımcıları değerlendirmek, bunun yanında yasal zorunluluğu da yerine getirmek için bir sınav yapılmaktadır. Katılımcıların ortalaması yazılı sınav için $94.8 \pm 4.7$, uygulama sınavı için ise $95.5 \pm 4.5$ idi. Ön test, son test, yazılı sınav ve uygulama sınav sonuçları arasında meslek, uzmanlık, çalışılan yer ve cinsiyet yönünden fark bulunmaktayd.

Sonuç: Araştırma grubumuzda NRP eğitimi, sağlık çalışanlarının bilgi ve becerisinde anlamlı bir artış sağlamıştır. NRP'nin uygulama üzerine etkisini değerlendirmek için katılımcıların beceri düzeyleri eğitim sonrası takip döneminde değerlendirilmelidir.

Anahtar kelimeler: Yenidoğan canlandırması, hizmet içi eğitim, asfiksi

Alındığı tarih: 22.06 .2015

Kabul tarihi: 20.07.2015

Yazışma adresi: Dr. Başak Tezel, Türkiye Halk Sağlığı Kurumu, Çocuk ve Ergen Sağlığı Daire Başkanlığı, Ankara

e-mail: basaktezel@yahoo.com 


\section{INTRODUCTION}

"If the child does not breathe immediately upon Delivery, which sometimes it will not, especially when it has taken Air in the womb; wipe its Mouth, and press your Mouth to the Child's, at the same time pinching the Nose with your Thumb and Finger, to prevent the Air escaping; inflate the lungs; rubbing it before the Fire; by which Method I have saved many."

\section{Dr. Benjamin Pugh-1754 (1)}

There has been a global decrease in child deaths during the end of the $20^{\text {th }}$ century. The latest estimates of under-five mortality from the Inter-agency Group for Child Mortality Estimation (IGME) show a 41 percent decline in the global under-five mortality rate, from 87 (85-89) deaths in 1990 to 51 (51-55) per 1,000 live births in 2011. Over the last 22 years all regions have seen slower reductions in neonatal mortality relative to under-five mortality. Globally, neonatal mortality has declined from 32 deaths per 1,000 live births in 1990 to 22 deaths per 1,000 live births in 2011 at an average of 1.8 percent a year which is much slower than for under-five mortality rates $(2.5$ percent per year) ${ }^{(2)}$. Child survival programs have primarily focused on important causes of death after the first 4 weeks of life such as pneumonia, diarrhea, malaria and vaccine-preventable conditions ${ }^{(3)}$ (resulting in a decline in under-5 mortality rates). While important, the concomitant lack of attention to important causes of neonatal mortality like preterm birth (the single largest cause of neonatal mortality, contributing to $35 \%$ of neonatal deaths) has resulted in neonatal deaths taking an increasing proportion of under-5 deaths (from $37 \%$ in 1990 to $40 \%$ in 2010), and demonstrating a slower rate of decline than that for under-5 mortality rates ${ }^{(4)}$.

Turkey, an upper middle income country, has made significant progress in health care over the past decade. Health system transformation was comprehensive, but maternal and neonatal health policies, in particular, played a central role ${ }^{(5)}$. As a result, neonatal mortality rate dropped from 29 deaths per 1,000 live births in 1990 to 9 deaths per 1,000 live births in $2011^{(2)}$. Childbirths with the aid of a skilled attendant rose from $83 \%$ in 2003 to more than $90 \%$ in 2009 , and institutional facility births rose to more than $90 \%$ by $2009^{(6)}$. In fact, Turkey achieved a decline in neonatal mortality rates in a decade which is accomplished only within 30 years in the OECD countries. Turkey have made great investments to improve health systems, such as systematizing referrals to neonatal care with transport systems, upgrading neonatal intensive care units, focusing on nursing staff skills and standardization of care especially for neonatal resuscitation ${ }^{(7)}$.

Birth is the starting point of a new life. Although it is a natural process, sometimes help may be needed. The most challenging part of the delivery is the transition from intrauterine life in water to extrauterine life of breathing air. Almost $90 \%$ of the babies make the transition without difficulty, while $10 \%$ may require some assistance. In $1 \%$ of all deliveries, babies may need extensive resuscitation ${ }^{(8)}$.

Birth asphyxia accounts almost $23 \%$ of 4 million neonatal deaths occurring annually ${ }^{(9)}$. Most of these babies were not resuscitated appropriately ${ }^{(8)}$. Deaths due to asphyxia are important, because they are relatively easy to avoid. Thousands of newborns will be able to be saved from death or injury by the use of correct resuscitation techniques. Neonatal Resuscitation Program (NRP) aims to support the delivery room staff with up-to-date knowledge and promote them to gain skills in neonatal resuscitation.

The effectiveness of the training to achieve the goals of program should be revealed. Lancet Neonatal Survival Team reported in 2005 that, neonatal resuscitation achieved a $6-42 \%$ decrease in all causes of neonatal mortality and morbidity with $95 \%$ cost- efficiency rates ${ }^{(10)}$. NRP trainings first began in USA in mid- seventies ${ }^{(11)}$. NRP trainings were first started as a local activity of Izmir Chamber of Medicine in Turkey in 1992 which was structured in accordance 
with American Academy of Pediatrics (AAP) and American Heart Association (AHA) guidelines. Starting from 1998, this program has been disseminated through the country by General Directorate of Mother and Child Health and Family Planning with the support of Izmir Chamber of Medicine in terms of training material. Target group for the NRP-Turkey is the health workers who have responsibilities for the mother and the baby during delivery. From 1998 until the end of 2007, 18749 health workers successfully completed this training ${ }^{(12)}$.

NRP Provider Courses are given in two groups. Group A consists of health workers other than physicians, and Group B consists of physicians. Lectures which are given to Group A concern asphyxia, resuscitation organization, initial steps following delivery, ventilation, compression, preparation and help for intubation, preparation of drugs and highlights of special conditions and preterm baby. While Group B receives lectures on intubation, drugs, special conditions and preterm which are more detailed than Group A lectures. NRP instructor course in Turkey is organized as classroom lectures and practice sessions unlike AAP courses which are based on self-teaching. Courses are given to groups of 15-25 health workers for 3 days. All participants are given a Neonatal Resuscitation Textbook which was translated into Turkish, adapted and updated. For practice sessions, intubatable baby manikins and all necessary resuscitation equipment are used. Standard slide sets are used for classroom sessions. NRP provider course was consisted of 6 lessons until 2007 which included 1. Asphyxia and organization of resuscitation, 2. Initial steps, 3. Ventilation, 4. Chest compression, 5. Intubation, 6. Medication. In 2007, lessons for special conditions and preterm baby were added and the total number of lessons encompassed 8 subjects ${ }^{(10)}$.

In this study we aimed to measure the change of the knowledge level in NRP course participants and the factors effecting success of participants. Participants' level of knowledge on neonatal resuscitation were assessed before and after training. Also effect of occupation, working place and specialty on the level of success was measured.

\section{MATERIAL and METHODS}

In this study, NRP courses given within the last 6 months of 2007 in 20 provinces namely, Adiyaman, Ankara, Antalya, Bingöl, Bitlis, Burdur, Bursa, Denizli, Diyarbakır, Elazı $\breve{g}$, Erzurum, Gaziantep, İstanbul, İzmir, Kars, Kayseri, Konya, Trabzon, Van and Bayburt were evaluated. It was a descriptive type study.

In 2007, pre-test NRP provider courses were started to be given and 3422 health workers attended 157 NRP provider courses in the whole country. Study group consisted of 1411 health workers who attended 71 NRP courses during the study period (second half of 2007).Within this time period pre-test assessments were started to be performed during NRP provider courses.

Dependent variables were pre-test, post-test, final written exam and practice exam results of the participants. Independent variables were occupation and working place of the participants (Table 1). Differences between 2 groups (Group A consisted of health workers (excl physicians) such as nurses, midwives, paramedics, etc and Group B consisted of physicians) were analyzed.

Data was extracted from "Course Reports" which were used to record NRP Provider Course data and pre-test answer sheets which were filled up by participants. Pre-test was consisted of 20 multiple choice question, final exam had 20 short-answer plus 80 multiple choice questions amounting to a total of 100 questions. The first 20 questions of the final exam, which were the same questions contained in the pretest was considered as post-test questions.

For statistical analysis SPSS for Windows version 13.0 was employed. Chi-square test was used to determine significant differences between frequency distributions, while t- test and variance analysis were used for measured variables, and in intergroup comparisons level of statistical significance was accepted as $\mathrm{p}<0.05$. 


\section{RESULTS}

Of the 1411 participants, $98.5 \%$ successfully completed the course and final exams and qualified for the certificate. Failure reasons were as follows; 6 participants could not attend all sessions $(0.40 \%), 14$ failed in the final exam $(13(0.90 \%)$ in the writtenand $1(0.07 \%)$ in the practice exam). Examination results were calculated on a 100 point-scale. Mean scores for the pre-test and post-test exams were $56.6 \pm 14.7$, and $95.4 \pm 5.1$ points, respectively. There was a significant difference between mean scores of the physicians (Group B) $(61.2 \pm 12.6)$ the other health workers (Group A) $(52.9 \pm 15.3),(\mathrm{p}<0.05)$. In Group $B$, practitioners had the lowest $(56.6 \pm 12.4)$, while anaesthesiologists the highest mean scores $(67.5 \pm 10.6)$ with a significant intergroup difference $(p<0.05)$. For group A, there was no significant difference within

Table 1. Distribution of the participants of NRP Provider Courses in Turkey 2007 according to sex, working place and occupation.

\begin{tabular}{|c|c|c|c|c|c|c|c|}
\hline \multicolumn{3}{|c|}{ Group A } & \multicolumn{3}{|c|}{ Group B } & \multicolumn{2}{|c|}{ Total } \\
\hline & $\mathbf{n}$ & $\% *$ & & $\mathbf{n}$ & $\% *$ & $\mathbf{n}$ & $\% *$ \\
\hline \multicolumn{8}{|l|}{ Working place } \\
\hline $1^{\text {st }}$ level facilities & 42 & 5,0 & $1^{\text {st }}$ level facilities & 34 & 6,0 & 76 & 5,4 \\
\hline $2^{\text {nd }}$ level facilities & 539 & 63,6 & $2^{\text {nd }}$ level facilities & 229 & 40,6 & 768 & 54,4 \\
\hline $3^{\text {rd }}$ level facilities & 208 & 24,6 & $3^{\text {rd }}$ level facilities & 246 & 43,6 & 454 & 32,2 \\
\hline Other & 58 & 6,8 & Other & 55 & 9,8 & 113 & 8,0 \\
\hline \multicolumn{8}{|l|}{ Occupation } \\
\hline Midwife & 414 & 48,9 & Pediatrician & 163 & 28,9 & & \\
\hline Nurse & 340 & 40,1 & Obstetrician & 119 & 21,1 & & \\
\hline Anesthesia Technician & 62 & 7,3 & Practitioner & 186 & 32,9 & & \\
\hline Paramedic & 17 & 2,0 & Anesthesiologist & 66 & 11,7 & & \\
\hline Health Officer & 11 & 1,3 & Family Practitioner & 21 & 3,7 & & \\
\hline Other & 3 & 0,4 & Other & 9 & 1,7 & & \\
\hline Total & 847 & 100,0 & Total & 564 & 100,0 & 1411 & 100,0 \\
\hline
\end{tabular}

*column percentage

Table 2. Mean pre- and post-test scores of NRP participants according to sex, occupation and level of facility, Turkey 2007.

\begin{tabular}{llccc}
\hline & Group & n & Mean of pre-test & Mean of post-test \\
\hline Occupation & Group A & & & $95,7 \pm 5,6$ \\
& Midwife & 412 & $52,3 \pm 14,8$ & $95,0 \pm 5,6$ \\
& Nurse & 336 & $54,5 \pm 15,8$ & $95,6 \pm 5,6$ \\
& Anesthesia Technician & 61 & $54,8 \pm 14,6$ & $96,3 \pm 5,3$ \\
& Paramedic & 15 & $53,1 \pm 17,9$ & $95,0 \pm 4,5$ \\
& Health Officer & 10 & $54,2 \pm 15,9$ & $93,3 \pm 7,6$ \\
& Other & 3 & $46,7 \pm 10,4$ & $98,3 \pm 3,2$ \\
& Group B & & & $97,7 \pm 3,5$ \\
& Pediatrician & 160 & $64,1 \pm 11,0$ & $96,7 \pm 5,3$ \\
& Obstetrician & 117 & $60,5 \pm 10,7$ & $98,4 \pm 2,8$ \\
& Practitioner & 183 & $56,6 \pm 12,4$ & $97,9 \pm 3,4$ \\
Anesthesiologist & 65 & $67,5 \pm 10,6$ & $98,7 \pm 3,5$ \\
Working place & 21 & $64,5 \pm 13,6$ & $91,9 \pm 8,8$ \\
& Family Practitioner & 8 & $57,5 \pm 11,0$ & $96,0 \pm 5,1$ \\
& Other & 75 & $46,2 \pm 12,7$ & $96,8 \pm 4,7$ \\
& $1^{\text {st level facilities }}$ & 761 & $53,5 \pm 15,1$ & $97,6 \pm 4,9$ \\
& $2^{\text {nd level facilities }}$ & 446 & $61,6 \pm 12,6$ & $96,3 \pm 5,1$ \\
\hline
\end{tabular}


the group (Table 2).

Differences between the pre and post-test mean scores of Groups A and B were significant. But higher increases were detected in Group A. Regarding occupation and level of facility, there was a significant difference between pre- and post-test results. Since each group had nearly similar post-test results, the groups with the lowest pre-test results demonstrated maximum differences relative to post-test results (Table 2). In Group A, the difference between pre-, and post-test results was at its highest level among midwives (52.3 \pm 14.8 points). In Group B, "physicians of other specialties " had the highest increase with $57.5 \pm 11.0$ points. Physicians of other specialties include pediatricians, obstetricians, anesthesiologists, practitioners and family physicians. They were usually in administrative positions or trained to be instructors. Among participants from primary health centers pre-test $(46.2 \pm 12.7)$ and posttest results were extremely different $(91.9 \pm 8.8)$.

When the success rate was analyzed for individual lessons, "Preterm Baby" (Lesson 8) had the highest scores with $83.5 \%$. Scores of the other lessons from highest to lowest success rates achieved were; Overview and Principles of Resuscitation (Lesson 1) 72.0\%, Initial Steps (Lesson 2) 69.4\%, Chest Compression (Lesson 4) 54.6\%, Special Conditions (Lesson 7) 51.3\%, Medications (Lesson 6) 48.9\%,
Ventilation (Lesson 3) 34.9\%, and Intubation (Lesson 5) $33.3 \%$. The greatest difference between Groups A and B was in "Medication" subject which was in favor of Group B (physicians ). Group A had a higher average score in Special Conditions (Lesson 7) and there was no difference between esson 7, and Lesson 1 (Overview and Principles of Resuscitation). For all other lessons, Group B had a higher mean score. Groups A and B had gotten better results in post-test than pre-test exams.

Post-test results were better than pre-test results in both groups. In both groups the greatest difference was in "Intubation" lesson. In Group A there was a $66.7 \%$ and in Group B $60.0 \%$ increase in success rates. The smallest intergroup difference was detected for lesson 8, "Preterm Baby" (Group A 21.2\% and Group B 5.3\%). Details of the pre- and post-test results are given in Figures 1 and 2.

Mean score of the written exam was $94.8 \pm 4.7$ points, while Group B had a higher score than Group A (96.4 \pm 3.5 vs $93.8 \pm 5.0)$. Mean score of the practice exam was $95.5 \pm 4.5$, and again Group B had a higher score (96.3 \pm 4.2 vs. $95.0 \pm 4.6)$ than Group A.

Any difference was not found in Group A as for the distribution of analyzed exam results, but in Group B pediatricians, obstetricians and anaesthesiologists had obtained significantly better results than practitioners. When the working place and the results

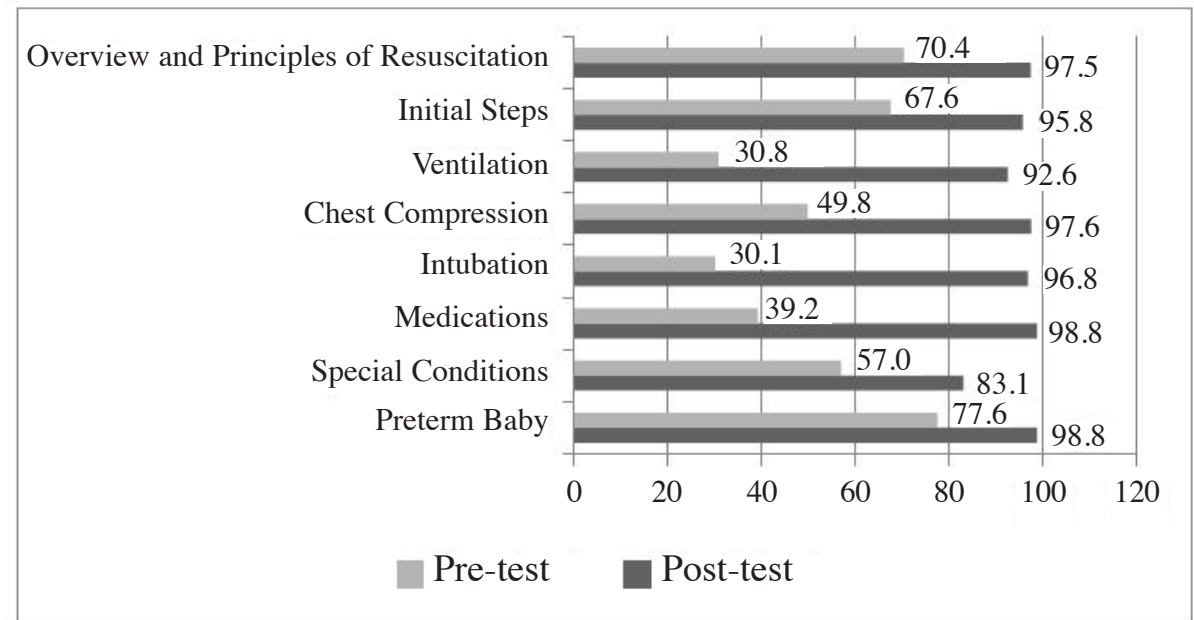

Figure 1. Pre- and post-test scores of NRP participants in Group A. 


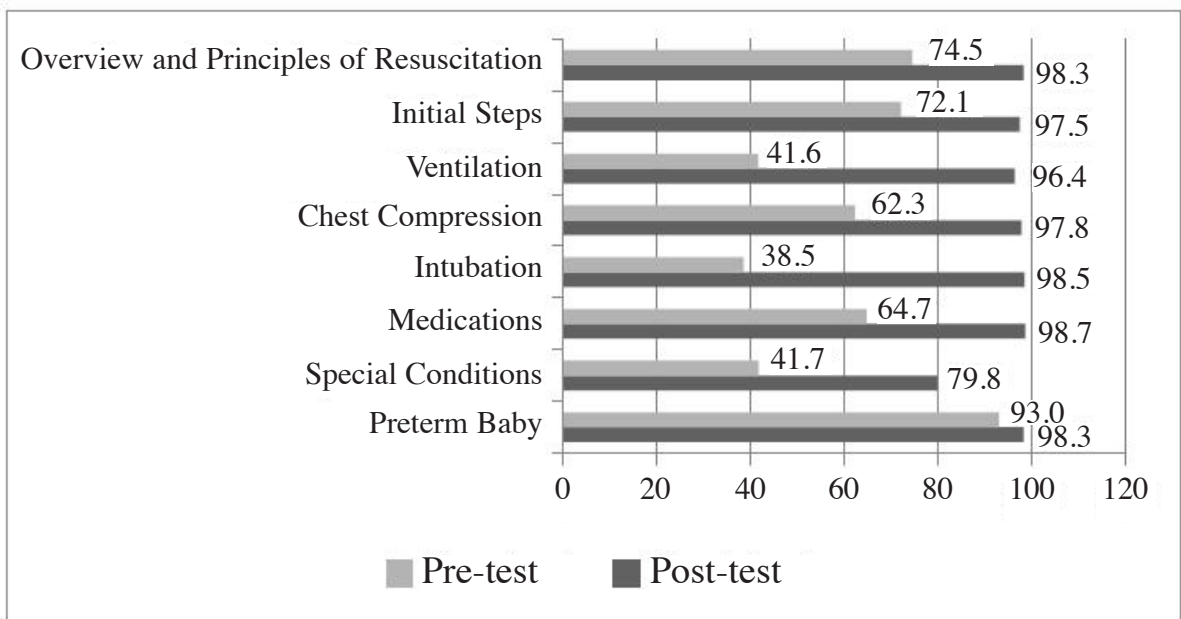

Figure 2. Pre- and post-test scores of NRP participants in Group B.

Table 3. Mean final written and practice exam scores of NRP participants according to sex, occupation and level of facility, Turkey 2007.

\begin{tabular}{|c|c|c|c|c|}
\hline & & & Written exam & Practice exam \\
\hline & Group & $\mathbf{n}$ & Mean & Mean \\
\hline \multirow[t]{16}{*}{ Occupation } & Group A & & & \\
\hline & Midwife & 412 & $93,6 \pm 4,9$ & $94,7 \pm 4,5$ \\
\hline & Nurse & 336 & $94,2 \pm 5,4$ & $95,1 \pm 4,9$ \\
\hline & Anesthesia Technician & 61 & $93,9 \pm 4,2$ & $96,1 \pm 3,9$ \\
\hline & Paramedic & 15 & $93,2 \pm 5,5$ & $96,8 \pm 3,8$ \\
\hline & Health Officer & 10 & $91,5 \pm 3,8$ & $95,9 \pm 2,5$ \\
\hline & Other & 3 & $93,8 \pm 4,4$ & $93,7 \pm 4,9$ \\
\hline & Total & 837 & $93,8 \pm 5,0$ & $95,0 \pm 4,6$ \\
\hline & Group B & & & \\
\hline & Pediatrician & 160 & $97,7 \pm 2,6$ & $97,2 \pm 3,5$ \\
\hline & Obstetrician & 117 & $97,3 \pm 2,9$ & $97,0 \pm 3,3$ \\
\hline & Practitioner & 183 & $94,6 \pm 4,1$ & $94,7 \pm 5,3$ \\
\hline & Anesthesiologist & 65 & $96,9 \pm 2,6$ & $96,8 \pm 3,4$ \\
\hline & Family Practitioner & 21 & $95,6 \pm 3,2$ & $96,3 \pm 4,4$ \\
\hline & Other & 8 & $95,7 \pm 4,8$ & $96,7 \pm 2,5$ \\
\hline & Total & 554 & $96,4 \pm 3,5$ & $96,3 \pm 4,2$ \\
\hline \multirow[t]{4}{*}{ Working place } & $1^{\text {st }}$ level facilities & 75 & $93,2 \pm 4,2$ & $93,9 \pm 4,6$ \\
\hline & $2^{\text {nd }}$ level facilities & 761 & $94,2 \pm 4,6$ & $95,1 \pm 4,3$ \\
\hline & $3^{\text {rd }}$ level facilities & 446 & $96,2 \pm 4,6$ & $96,4 \pm 4,9$ \\
\hline & Other & 109 & $94,5 \pm 4,2$ & $95,6 \pm 4,1$ \\
\hline Total & & 1391 & $94,8 \pm 4,7$ & $95,5 \pm 4,5$ \\
\hline
\end{tabular}

were analyzed, health workers from tertiary helath centers had significantly better results (Table 3 ).

\section{DISCUSSION}

Asphyxia has an important role in neonatal mortality and morbidity. Preventing death and sequelae due to asphyxia would be possible if health workers trained in neonatal resuscitation attend deliveries. Eleven NRP training sessions were designed regarding the needs of the delivery room staff to achieve optimum management of the newborn.

Efficiency of NRP training could be evaluated by two methods: Assessing impact of NRP on neonatal 
health (neonatal death rate, reasons for neonatal deaths, etc) or analyzing the difference in the knowledge level and skill of NRP course participants.

Our study aimed to assess differences in knowledge and skill levels before and after NRP courses. Our study revealed that health workers trained in NRP courses increased their knowledge and skills, and our results were in accordance with other studies in the same field ${ }^{(13-15)}$. But we could not find any study evaluating pre-test, and post-test results based on the participant's occupations. Only Couper et al reported higher success rates for physicians in a similar study, but it was not stated whether the difference was significant or not ${ }^{(13)}$.

When pre-test results of both groups were compared with respect to lessons, there was no difference except for the Lesson $1(\mathrm{p}<0.05)$. Group A participants were more successful only in Lesson 7. This lesson is related with special conditions, and had only one question in the pre-test, which was about routine care. Group A participants were naturally expected to be more successful in this subject. Biggest difference between two groups was in lessons for drugs. This can be explained by the differences in the curriculum of health workers. Another interesting result was that, participants had very low scores in "Ventilation", which is the key process in neonatal resuscitation. This low score was seen either within the whole group (34.9\%) or between different groups (Group A $30.8 \%$, Group B $41.6 \%$ ). There was no difference between two groups with respect to occupation in the "Ventilation" lesson ( $\mathrm{p}<0.05)$. This could be a sign of underestimation during pre-service training.

In a study conducted by Trevisanuto et al. at Padua in 2004, 25 fellows of pediatrics were given a pre-test consisting of 80 questions before a course prepared in accordance with AAP/AHA recommendations. Among the major subjects could be listed as "Initial steps", "Ventilation", "Chest Compressions" and "Medication" and highest scores were achieved in "Initial Steps" followed by "Ventilation" in which only $40 \%$ of the patients passed the test. The lowest scores were obtained in "Chest Compression" course.
${ }^{(9)}$. In our study in the physicians group, success rates were as follows: Initial Steps (72.1\%), Medication (64.7\%), ChestCompressions (62.0\%), and Ventilation $(41.6 \%)$. In our study, success rates were higher and the order of the subjects was different. In our study participants'knowledge level was higher concerning Medications when compared with Ventilation and Chest Compression. In a study by Trevisanuto et al. participants were more knowledgeable in the Compression course. Only $0.2 \%$ of the participants were successful in the Neonatal Resuscitation course which did not meet the real needs ${ }^{(8)}$.

When each lesson was evaluated separately, overall success rate of the participants for all lessons was over $90 \%$ except for Lesson 7 with a success rate of $82.2 \%$. The biggest difference between pre- and posttest exam results were obtained in Lesson 5-Intubation, as could be expected, while the smallest difference between both test results was noted in Lesson 8-Preterm Baby. There was also a significant difference between the pre- and post-test results of each question $(\mathrm{p}<0.05)$.

Re-evaluating knowledge and skill levels of the participants following a certain time after the course is considered to be valuable. Trevisanuto et al showed that participants had lower rate of success 6 months after the course, when compared to post-test results (14). This information is adapted to our program with update trainings every third year following the course since 2004.

\section{CONCLUSIONS}

1. It should be noted that, there was a considerable lack of knowledge about ventilation, which is the key element of neonatal resuscitation. NRP trainings are in-service trainings and given to a special group of health workers and therefore they are not suitable for integrating into pre-service training as it is. But the results have demonstrated us that basic neonatal resuscitation should be part of the pre-service training.

2. Fellows of pediatrics, obstetrics and anaesthesiol- 
ogy should complete the course before they finish their fellowship. Especially the lower rate of success which was found among obstetricians, who are responsible from most of the deliveries, is an important issue.

Conflicts of Interest: None of the authors have a conflict of interest.

Acknowledgements: Thanks to the members of the NRP training team, which are a big family, and Dr Rifat Köse who made this study possible.

\section{REFERENCES}

1. Pugh B, A Treatise of Midwifery, London; 1754.

2. Levels and Trends in Child Mortality, Report 2012. Geneva: UNICEF, World Health Organization, The World Bank, the United Nations Population Division.

3. Martines J, Paul VK, Bhutta ZA, Koblinsky M, Soucat A, Walker $\mathrm{N}$ et al. for Lancet Neonatal Survival Team. Neonatal survival: a call for action. Lancet 2005;365(9465):1189-1197. http://dx.doi.org/10.1016/S0140-6736(05)71882-1

4. Oestergaard MZ, Inoue M, Yoshida S, Mahanani WR, Gore FM, Cousens S, et al. Neonatal mortality levels for 193 countries in 2009 with trends since 1990: a systematic analysis of progress, projections, and priorities. PLoS Med 2011;8(8):e1001080. http://dx.doi.org/10.1371/journal. pmed.1001080.

5. Howson CP, Kinney MV, Lawn JE (Eds). March of Dimes, PMNCH, Save the Children, WHO. Born Too Soon: The Global Action Report on Preterm Birth. World Health Organization. Geneva, 2012.
6. Demirel G, Dilmen U. Success of Decreasing Neonatal Mortality in Turkey. Medical Journal of Islamic World Academy of Sciences 2011;19(4):161-164.

7. Baris E, Mollahaliloglu S, Aydin S. Healthcare in Turkey: from laggard to leader. BMJ 2011;342:c7456. http://dx.doi.org/10.1136/bmj.c7456

8. Neonatal Resuscitation Textbook, $6^{\text {th }}$ edition, American Hearth Associtation, American Academy of Pediatrics, 2011, p2 (ISBN -13:978-1-58110-498-1).

9. Joy E, Simon C, Jelka Z. 4 million neonatal deaths: When? Where? Why? Lancet 2005;365(9462):891-900. http://dx.doi.org/10.1016/S0140-6736(05)71048-5

10. Gary L, Zulfiqar A, Simon C, Taghreed A, Neff W. Neonatal Survival 2: Evidence-based, cost-effective interventions: how many newborn babies can we save? Lancet (serial online). 2005 March: Available from: URL: http://image. thelancet.com/extras/05art1217 web.pdf

11. Bloom R, Catherine C. The Early History and Basic Concepts of the Neonatal Resuscitation Program; 1997. Available from: URL: http://www.aap.org/nrp/about/about_historyconcepts.html

12. T.C. Sağlık Bakanlığı Ana Çocuk Sağlığı ve Aile Planlaması Genel Müdürlüğü. Neonatal Resüsitasyon Programı Yıllık Raporlar1. Ankara; 1998-2001, 2002, 2003, 2004, 2005, 2006, 2007

13. Couper ID, Thurley JD, Hugo JFM. The Neonatal Resuscitation Training Project in Rural South Africa. Rural and Remote Health. 2005; November: 459. Available from: http://www.rrh.org.au

14. Trevisanuto D, Ferrarese P, Cavicchioli P, Fasson A, Zanardo V, Zacchello A. Knowledge gained by pediatric residents after neonatal resuscitation program courses. Pediatric Anesthesia 2005;15:944-947. http://dx.doi.org/10.1111/j.1460-9592.2005.01589.x

15. Ergenekon E, Koc E, Atalay Y, Soysal S. Neonatal resuscitation course experience in Turkey. Resuscitation 2000;45:225227. http://dx.doi.org/10.1016/S0300-9572(00)00179-9 